\title{
Augustus - Making a Legacy of the Pax Deorum Aspects of a Pagan Attempt at Religious Revival Shortly Before the Birth of Christ
}

\author{
By David P. Wick
}

My intent in this study - the finishing part of three - has been to examine the attempt by Augustus build a legacy (after the Mediterranean-wide efforts of the year 17 of the old era) that would graft in place the transformative events he had tried to define and publicize in the Ludi Saeculares, to re-create the family religious solidarity and wholeness of community he and his wife believed the Roman world needed to survive. The first part investigated the widespread feeling in the Mediterranean at the time of Actium that human culture had become so destructive and infected by guilt and ambition it might itself end in war or social disaster, the second, the "engineering" of the event itself. In this final portion of the study I look at choices Augustus and those around him made to craft a legacy of the themes of the Saeculares event itself-choices in temple construction, religious dedication (and choices of which themes to highlight around the Mediterranean), choices of iconography and religiously redefined politics. I intend to sketch the aftermath of the belief-experience built at the Saeculares (looking at how Augustus and his wife may have assessed the impact they made, rather than the way it is assessed as successful propaganda or narrative construction today) and in particular at its application to the army and the Roman idea of military power vs. peace. What Augustus had vowed he would do with his new power after the victory at Actium ended up looking very different by the year of the Saeculares, and was undermined (in our eyes) heavily by revolts in his family, fashionable artistic culture in Rome, even by his heir Tiberius, but largely, I would argue, because new choices Augustus (and his wife, his closest friends) made were genuine, but could not be engineered in the way he hoped. This (partial) failure was not the result only of a changing power-environment, or one well-crafted power narrative simply moving on from another.

"Phoebus [Apollo] and Diana of the forest Bright glory of the heaven sublime,

Worshipped and to be worshipped, grant our request

In a holy time,

When warned by the verses of the Sybils These pure boys and these chosen girls who belong

To the gods who have loved the seven hills

Repeat this song.

Kindly sun in your chariot gleaming,

Bringer and taker of day, for ever reborn Fresh and the same, may you never see anything

Greater than Rome. ...

\footnotetext{
*Professor of History, Gordon College, USA.

1. Part 3 of an Historical Case Study in Religious Motives. Part 1: David P. Wick, "Augustus and the Problem of the Pax Deorum - A Case Study in Social \& Religious Motives at the Birth of the Roman Empire," Athens Journal of Mediterranean Studies, 5, no.1(2019):1-10; Part 2: David P. Wick, "Augustus - The Engineering of Belief \& the Pax Deorum. Part 2 in a Serial Study of the Pax Deorum," in Athens Journal of Mediterranean Studies [forthcoming]
} 
...May the prophet glorious with his gleaming bow

Phoebus to whom nine Muses sing their hymns

Who with his saving art rescues from sorrow

Our weary limbs,

If he looks kindly on his Palatine

Altars continue happy Latium

And Roman wealth, and better things combine

In the age to come."

Classicists may recognize Peter Levi's translation of the Carmen Saeculare, the hymn centerpiece of an attempt by the emperor Augustus - and especially his wife Livia - to "engineer" a repentance and spiritual reawakening in the populace of the Roman world. I re-created this story in broad strokes in the first two installments of this study. It centered around the ritual week that featured the hymn, in the year 17 of the old era. I have tried to follow the efforts, and some of the meanings in this surprising project in those installment, originally presented at conferences of the ATINER institute held in Athens. But "felt need," (part one of the study) and effort at cultural engineering (part two) are not of course the same as results. In this finishing study I wish to follow some of the effects, the legacy if Augustus was to have one, as efforts at historic or political spiritual change. We often critique the ritual or the preaching (studies of Augustus default to the word "propaganda"), but take too little notice of the behavior of Augusts himself after the ceremonial year ended.

But for context I began with a bit of the hymn commissioned for Horace, with the focus of the Roman heart - the Mediterranean heart as it had become after Actium - on things greater than itself, connecting them to moral renewal. Propaganda or not, this the hymn was at least meant to do, and I think we fall far short of understanding the occasion unless we realize that if only one Roman was moved deeply, that one was Augustus. This was most particularly true where the hymn and the ritual touched on the temple and work of Apollo, who had always been the one source of clarity, light and communication whenever the rest of the Greek (and now the Roman) cosmos grew dark, uncertain, hostile. He could "tell you what to do when you felt anxious or frightened; he knew the rules of the complicated game that the gods play with humanity; he was the supreme alexikakoz, Averter of Evil'." ${ }^{3}$

Why Apollo, from a Roman reformer or at least ruler, in a Roman setting, intended for a Roman ceremony of "revival?" More than one Greek deity (Octavian had been raised by his father Philippus largely in Athens) could be made to have something to do with human arts in general, and government in particular. Dionysus was the patron or theatre in the sense of being Master of Illusion; he would fit the Augustan propaganda-analysts perfectly. And, Dionysus "traveled" well. He had been naturalized by the Hellenistic monarchs, especially in Egypt, who drew a great deal of temporal and emotional power from pageantry and display of wealth. And there was Hercules, seemingly

2. Horace, Carmen Saeculare, 11. 1-20, 60-72, again in P. Levi, Horace: a Life (New York: Routledge, 1998), 207-209.

3. E.R. Dodds, Greeks and the Irrational (Berkeley: University of California Press, 1981), 75. Cf. Aeschylus, Eumenides, $616 \mathrm{ff}$. 
obvious for the "strong-man" political type, a semi-deity who had an old connection with the Muses, though it that is often forgotten. Hercules could understand and sympathize with human acts or struggles, and at the same time hopefully keep them from losing their proper proportion, from provoking the jealousy of the gods. A common laborer in a moment of great effort was much safer saying "Hercule!" than "O Dionysus!" or (much worse) "O Zeus!"

I noted in the last study that this latter attitude seems to have been the one taken by the new emperor's father Philippus; it implied the humility he seems always to have tried to impress upon Octavian, but Octavian on the way to becoming Augustus chose Apollo as his defining principle instead. There was more to this than the happy accident of an Apolline temple overlooking the bay at Actium. ${ }^{5}$

Let me add a little to some notices from the last study to set the stage. Apollo had been evoked into and naturalized as a part of Rome in response to natural disaster in the year 431 B.C. ${ }^{6}$ He had been the protecting god of Troy, and Virgil in due course had his Aeneas land at the same holy site Octavian would one day camp beneath. In fact, Apollo carried enough religious weight with the young Octavian that Virgil could begin his fourth eclogue (40 B.C.) with the words "Your Apollo now reigns". Octavian may have made a small dedication to Apollo on the Palatine as early as $36 .{ }^{7}$ A thunderbolt hit the hill in 28 , making the place unchancy even to a skeptical mind of those times. ${ }^{8}$ Augustus saw no ambiguity in the message and set about temple-building quickly, later adding an impressively endowed library to its precincts. ${ }^{9}$

Apollo had I think been a useful guardian and identification at first simply because of the contrast with Antony, who had taken to Dionysus (and Egypt, and a queen who was heir in spirit to the old ecumenical culture-leveler Alexander). But the more he saw the forces of chaos, the less did Octavian wish to defeat them by becoming one of them. Apollo offered access, by contrast, to clarity, rightness, the sense of things, inspiration to decisions that could harmonize with heaven. ${ }^{10}$ To a Roman enmeshed in the business of becoming Augustus, full of private weaknesses, ironies and misgivings, Apollo seemed though Greek to offer the best chance at a return to intelligent, fertile

4. Cf . E.R. Dodds, "The Religion of the Everyday Man in Classical Greece," The Ancient Concept of Progress (Oxford, 1972).

5. Propertius IV, vi, 29 ff. Cf. Jean Gagé, Apollon romain. Essai sur le culte d'Apollon et le développement du "ritus Graecus" à Rome des origines à Auguste (Paris: De Boccard,1955), 229, 515. Compare Ronald Syme, The Roman Revolution (Oxford: Clarendon Press, 1939), 448, where a "happy" accident is almost all it is.

6. J. Gagé Apollon romain.

7. R.M. Ogilvie, The Romans and Their Gods in the Age of Augustus (Ancient Culture and Society) (New York: W. W. Norton and Company, 1969), 114.

8. Propertius, ii, 31. Suetonius, Augustus, 29. On Augustus, cf. W. Warde Fowler, Religious Experience of the Roman People (London: Macmillan, 1911), 305.

9. Suetonius, Augustus XXIX, 3.

10. Cf. Horace, Odes I, xxxi, which redefines Apollo's sphere of blessing toward a very modest harmony of life. The 'ironies and misgivings' set the stage for the apologia in the Res Gestae, but may also have been born of answering the charges of Antony, see M. Charlesworth, "Some Fragments of the Propaganda of Antony", Classical Quarterly (1933) and H. Jeanmaire, "La politique religieuse d'Antoine et Cléopatre", Revue Archéologique (1924), vol. XIX. 
Romanitas. When the Senate was un-enthusiastic about funds for a temple on the site, Augustus built it himself, using what little land still lay free behind his own, comparatively small, home.

So, the picture re-created of the Saeculares had its last stroked sketched under the porch and chariot of Apollo, in the new emperor's "back yard." Augustus made, or hoped he had made, a choice for his extended familia and subjects against the whole previous century of their heritage. He chose for them instead an image of the best things his optimistic and world-weary scholars could discover in the centuries before.

\section{Apollo vs. Mars: the Pax Deorum and the Armies}

I had mentioned earlier, though, and postponed, one "odd deity out" ... we would expect a successful victor at Actium and uniter of the Empire to feature Mars. This character I am trying to draw of Augustus is one who could stand genuinely moved at the close of the Saeculares and could place a restoration of religion high in the "template for Emperors" he bequeathed in writing to his heirs. Augustus had yet as the saecular festival ended done nothing about setting the pax deorum of the armies on a footing as firm and regenerate as he hoped his new empire to be. His were still in the last decades of the old era largely successful armies, but they were expensive and thinly spread. He had vowed building the temple to Mars Ultor back in the dimming past at Philippi when he only been Octavian, and not a very dashing Octavian at that. ${ }^{11}$ His legitimacy had rested on avenging Caesar, and even in those days (as with the case of the will and legacies) on carrying out Caesar's programs.

There could be no question now of raising a martial temple to celebrate the avenging and vindication of the Dictator, and Augustus seems to have spent no effort in propagandizing the groundwork for one. Caesar, except in the highly denatured form Divus Julius, had become a part of the dark chaotic past Augustus hoped to banish. A less religiously motivated man might over the years have let the idea slide slowly into oblivion. That Augustus could not in the end do so tells us something about him. Nevertheless, he did put it off for a long time, from the moment of victory (when it might have had the greatest propaganda value) until about 2 B.C. This is the man who rebuilt eighty two temples, ${ }^{12}$ who worked dedications to gods like Salus and Honos into the Carmen Saeculare. He had to deal with the issue someday.

For a time he seems to have hovered on the verge of deifying Pax in its place. Tibullus, rather on the fringes of the court circle appears to anticipate this. ${ }^{13}$ Pax has a role in the Carmen Saeculare (stanza 15), connected by Fides to the equally critical civic virtue Pudor, and the military Honos and Virtus. But the wars would not go away, though they might change in character, and the

11. Suetonius, Augustus xxix, 2, where the dedication was "in vengeance for his father".

12. Augustus, Res Gestae, 20. Augustus also required the heirs of earlier dedicators to restore or maintain the temples built by their forebears (Dio Cassius LIII, ii, 4).

13. Tibullus I, 10. 
doors of Janus kept opening. It is the change, not the vanishing, of his wars that Augustus seems so bent on emphasizing in the Res Gestae. ${ }^{14}$

The compromise (or synthesis) Augustus hit upon is interesting. He built the temple, dedicating it in 2 B.C, the year he became "Pater Patriae" and held his thirteenth consulship. ${ }^{15} \mathrm{He}$ even went so far as to make it the focus of much of the ritual and scrupulous business of Roman warfare. He carried through with the idea of assigning it to Mars Avenger. What very few historians seem to have noticed is how thoroughly Caesar disappeared as the avenged. Rather, the tenth chapter of Dio Cassius LV and the reminiscence in the Res Gestae seem to me to commemorate the refounding of the legions on the moral basis of vengeance as a limiting ideal. The occasion had not been some Caesarian anniversary but the return of legionary eagles lost long in Parthia by the adventurer Crassus. Crassus therefore becomes the one avenged. ${ }^{16} \mathrm{His}$, or Rome's, vengeance took place by diplomacy, though the chief diplomat (Tiberius) held a military commission. The mock naval battle Augustus staged for the event, which seems to have made a disproportionately powerful impression on the City, ${ }^{17}$ and which gets a whole chapter in the Res Gestae, ${ }^{18}$ was "Athenians" versus "Persians" rather than some archetypal Roman duel. The excessive care (to my eye at least) taken in the body of the Res Gestae to make no war appear as an aggression (-- the proem may carry the attitudes of an editor) is a sort of posthumous pleading by the elderly Augustus on a sensitive score. There were fewer wars aimed at revenue toward the end of his reign, and a correspondingly leaner treasury.

\section{The Mix of Results}

In the light of all this, we might do well to end with a word about the echoes of so much religious anxiety and effort aimed at redefinition and rebirth in the Res Gestae itself. The year of the dedication to Mars Ultor was not a very good one. While some Romans may have begun to share their princeps' concern about the pax deorum, a sort of immoralist revolt ${ }^{19}$ among some of the

14. Augustus, Res Gestae, 3, 13, 26, and the tone of the entire closing summary. Lidia Mazzolani strikes the note of this re-emphasis in the Res Gestae very well with the phrase that "the Empire is not like the universe, in keeping with the Divine Mind, but rather like a small farm, where the steward accounts for every penny spent." (The Idea of the City in Roman Thought (Indiana: Indiana University Press, 1970), 131). Augustus' step-father Philippus, who had been father-in-law to the younger Cato and always pressed his ward in the direction of humility and modest ambitions, would have approved of the Res Gestae -- as a limitation of imperial pretentions if not as a replacement for the Republic. It marked perhaps the last elimination of Julius Caesar's personality from the posthumous image of Augustus.

15. Dio Cassius LV, $\mathrm{x}$.

16. Dio Cassius LIV, viii, 1-3 is quite explicit on the point, as well as Ovid, Fasti V, 545599.

17. Dio Cassius LV, x, 7. Ovid, Ars Amatoria, i, $171 \mathrm{ff.}$

18. Augustus, Res Gestae, 33.

19. Seneca, who had lived through far worse, seems to regard this as common knowledge; De Brev. Vitae, iv, 6. A good example of the trend from outside the palace circle is Domitius Ahenobarbus: Suetonius, Nero, 4. Also Dio Cassius LV, x, 11 (10a:11 in the Loeb edition). 
young nobility and intellectuals blew up in Augustus' face. Julia, and her lovers, and the nouveaux fashionable set in which they move, were just part of a restless adolescent mutiny - Julia and the poet Ovid were only a couple of those prosecuted or exiled after in explosive civic scandals in the later years of the reign - with whose discontents Augustus failed either to sympathize imaginatively or to communicate (as he failed to impress the elder heroes of the movement that Ovid represented). ${ }^{20}$ Beside Julia's higher-born paramours there could be found apparently at least one impious Greek philosophe. ${ }^{21}$ Good times had removed the public feeling that the gods expected one to live virtuously on pain of a return of civil war, just as comparative peace at home had removed much of the Italian interest in military service. Julia's set were (or appear in our Augustan records as) snide, irreverent, ungrateful, completely oblivious to the disapproval of the gods ${ }^{22}$-- everything in short that a scrupulous old man dreaded. Tiberius retired from the scene in the face of only a moderate threat to his career, arousing sharp bitterness in Augustus. The old emperor wanted to retire himself, ${ }^{23}$ felt indeed that he deserved to after such a calamitous life ${ }^{24}$ one which only looked to grow worse -- but he could not.

How was the future of Rome to be assured? The great occasions of lavish recommitment and rebirth had come and gone; the Pater Patriae had to face in the twilight of his career a likelihood that he had convinced his more distant subjects better than those in the City, or those close around him. Everyone of the inner circle who had understood Augustus seemed gone. Tiberius was a moody, superstitious, literal-minded drudge, even if he could be coaxed back to Rome. Gaius and Lucius had been awkward projects to develop as future leaders, and both died young. Agrippa Postumus made a worse prospect, and was still alive.

When he wrote the Res Gestae Augustus aimed not so much at an epitaph or a eulogy as at a sort of template for future regimes. That I suspect is why copies of it were erected so widely in marketplaces throughout the provinces. It is a summary of Augustus and his imperium regenerate, posted forever (he hoped) in centers of government, recasting his reign in a way that would maintain the right relationship with those gods who might save Rome from the chaos. Augustus apparently believed with sincerity that his successors need only imitate it in its general drives and be ambitious to compare well with it in the minds of their subjects when they read it over again in some public place.

20. Augustus cannot have been reassured by the religious drift of Ovid's own Ars Amatoria: "the existence of the gods is convenient and, as it is convenient, let us assume it [expedit esse deos et, ut expedit, esse putemus]" (I, 645).

21. A certain Demosthenes. Macrobius I, xi, 7.

22. Velleius Paterculus II, c, 3 for Julia's definition of libertas. Such rising attitudes must have seemed to the older folk who had survived the Civil Wars like the beginning of the return of the Chaos. Macrobius II, v, 6 strikes a nastily authentic note if I have understood Augustus and the situation correctly.

23. Seneca, quoting an Augustan letter, in De Brev. Vitae, iv, 3.

24. It was as an example of patience enduring a string of unending calamities that sympathetic souls (particularly Stoics) came to view the personal life of Augustus. Pliny the Elder, for example, in Nat. Hist. vii, 149. 
That it became an epitaph was a signal of its failure. Like its author, it impressed those citizens in far-flung provinces better than it did his heirs. In the familia of Augustus there was a short-lived and pessimistic effort at maintaining the dry letter of his laws and after that (not long after) Tiberius repeated his retirement and the center of Rome found how quickly the chaos could return.

Where does this leave a modern historian of culture or politics? A few Christian historians have remembered (though they have seldom taken seriously) the argument of the Christian advocate Paul in his Roman letter that the pagan world did indeed "show the work of the law written on its hearts", "their conscience also bearing witness." ${ }^{25}$ A modern, political skeptic must explain the behavior of, or understand the motivations of not only Augustus, but the widespread populations that took such an energetic and affective part in the emotional changes of his era, an era confusingly close to, but significantly before the Christian preaching we often suppose to have "invented" cultural penitence or spiritual efforts at popular "revival?"

I note, finishing, that the usual academic answer begins with a wise, knowing nod and the word "propaganda," a reaction that perhaps says as much about the aggressive confidence of modern media scholarship and fashionable deconstructionism (and perhaps a hint that academic contempt for the hoi polloi has not disappeared) as it does about the problem being examined. There is an issue clearly sidestepped here: whether or not one applies the word "propaganda" heavily to the various acts and emotional transitions of the Augustan effort around the year 17 that has been the subject of my three studies. One still has to ask why any of this was effective propaganda, why it took the shape it did, and why so much of Augustus's formative career as a leader (and that of his wife Livia as a leader) could become so intensively hinged upon it. ${ }^{26}$

\section{Bibliography}

\section{Modern References}

Charlesworth, M. "Some Fragments of the Propaganda of Antony." Classical Quarterly (1933).

Dodds, E.R. The Ancient Concept of Progress. Oxford, 1972.

Dodds, E.R. Greeks and the Irrational. Berkeley: University of California Press, 1981.

Fowler, W. Warde. Religious Experience of the Roman People. London: Macmillan, 1911.

Gagé, Jean. Apollon romain. Essai sur le culte d'Apollon et le développement du

25. Epistle to the Romans, ii, 15 and the long arguments leading up to the statement.

26. This material written for presentation at the ATINER $15^{\text {th }}$ Annual International Conference on History \& Archaeology: From Ancient to Modern, Athens, Greece, 2017, and revised with feedback from that presentation. My thanks to all who contributed, however informally. 
"ritus Graecus" à Rome des origines à Auguste. Paris: De Boccard, 1955.

H. Jeanmaire, "La politique religieuse d'Antoine et Cléopatre." Revue Archéologique (1924), vol. XIX

Levi, P. Horace: a Life. New York: Routledge, 1998. [also used for translated selections].

Mazzolani, Lidia Storoni. The Idea of the City in Roman Thought. Indiana: Indiana University Press, 1970.

Ogilvie, R. M. The Romans and Their Gods in the Age of Augustus (Ancient Culture and Society). New York: W. W. Norton and Company, 1969.

Syme, Ronald. The Roman Revolution. Oxford: Clarendon Press, 1939.

Ancient References (each locus in notes as appropriate)

Appian, Civil Wars

Augustus, Res Gestae

Cicero, Ad Atticus, Ad Quintus, De Officiis

Dio Cassius, Histories

Horace, Odesm Carmen Saeculare

Livy, Histories (esp bk. III)

Nepos, Lives (esp. Atticus)

Plutarch, Antony, Pompey, Crassus, Caesar, Cato

Pompeius Trogus, History of Rome

Seneca, de Beneficiis

Suetonius, Augustus, Julius Caesar

Velleius Paterculus, History of Rome 